\title{
Micro-computed Tomography Study of Root Canal Anatomy of Permanent Mandibular Canines
}

\author{
Fernanda Moura Antonialli, ${ }^{1}$ Alexandre Rodrigues Freire, ${ }^{1}$ Rafael Araujo,' Sarah Teixeira Costa, ${ }^{1}$ Felippe Bevilacqua \\ Prado, ${ }^{1}$ Ana Claudia Rossi ${ }^{1}$
}

'Department of Morphology, Anatomy division, Piracicaba Dental School, Campinas State University, Piracicaba, SP, Brazil

Disclose and conflicts of interest: none to be declared by all authors

\begin{abstract}
Introduction: root canals morphology knowledge is important in order to achieve success in endodontics treatments. Accessory roots have been reported in mandibular anterior teeth, and it is necessary to improve better and new diagnostic methods, such as micro-CT. The aim of this study was to investigate the internal and external anatomy of human permanent mandibular canine teeth using micro-CT. It was used 50 permanent mandibular canine teeth with complete rhyzogenesis. Deciduous teeth, teeth with deep caries, fractures, incomplete rhyzogenesis and those that presented with obturated root canal were excluded. The samples were scanned in a microtomography (SkyScan 1174, Belgium) by using $50 \mathrm{kV}, 800 \mathrm{~mA}$. The thickness of the slices was $6 \mu \mathrm{m}$. After three-dimensional reconstruction, the images were transferred to Mimics v. 18 (Materialise, Belgium) for analysis of the internal anatomy of the roots of the mandibular canines. Canines were classified in types I to VIII. The external anatomy of the root was analysed and classified regarding according to the existence or not of the mesial radicular grooves. The R CRAN (WU Wien, TU Dortmund, U Oxford, AT\&T Research) software was used for statistical analysis. Descriptive analysis was performed by percentage to verify the most frequent root canal type in the lower canines. The descriptive analysis was performed in the form of a decision tree. The level of significance was $<0.05$. Three-dimensional reconstruction of the internal anatomy revealed that the most frequent canal was type I (92\%), followed by type III ( $8 \%$ ).

Keywords: Morphology, Micro-ct, Root canal, Canines.
\end{abstract}

\section{Introduction}

The success of endodontic treatment is related to knowledge of the internal anatomy of the tooth. Endodontic treatment requires, from the professional, access to the pulp cavity, which is not visualized macroscopically and in its entirety during therapy. Therefore, the professional should present a broad knowledge of the root canal morphology, as well as a possible and constant variations, which may interfere in the success of the treatment. ${ }^{1,2}$

One of the main responsible for failure of endodontic therapy is incomplete fillings or presence of untreated root canals. These cases of anatomical complexities generate the permanence of microorganisms in intact areas that become inaccessible and not totally obturated, disfavouring the endodontic therapy.,4,5 Thus, the total knowledge of the internal and external morphology of the teeth becomes imperative in the clinical evaluation., 6

The existingtechniquesfor the detection of accessory root canals are as follows: clinical investigation, radiographic studies, dye infiltration, studies using optical microscopy, clinical microscopy, electron microscopy, clearing techniques and computed tomography. In many studies, the combination of these various techniques is used to obtain better results. ${ }^{7}$
Currently, micro-computed tomography (micro-CT) is being used to evaluate the anatomy of root canals due to their high resolution and non-destruction of specimens. ${ }^{8,9}$

The internal anatomy of the permanent mandibular canines generally accompanies the external anatomy; Thus, the pulp chambers accompany the shape of the respective crowns, but the root canals usually present a flattening in the mesio-distal direction and, therefore, a widening in the lingual-lingual direction, mainly in the middle third. At this site the canal can branch, not following the external anatomy of the root, a dentine islet forms between the buccal and lingual root canals. Most often the root canals fuse again and end up in a single apical foramen..$^{10}$ The dentine islet is formed due to the presence of proximal longitudinal sulci present, especially in the distal faces of the mandibular canines. The mandibular canine can also present the bipartition of the root apex and may even generate two roots. ${ }^{11}$

The present research is justified because accessory roots have been reported in mandibular anterior teeth, and numerous supplemental configurations have been identified in different population groups using methods such as staining and clearing. ${ }^{12,13}$ Thus, the aim of this study was to investigate the internal and 
external anatomy of human permanent mandibular canine teeth using micro-CT.

\section{Material and Methods}

This study was approved by the Ethics Committee of the Piracicaba Dental School - UNICAMP (protocol number: 50249315.9.0000.5418).

\section{Sample distribution}

We used 50 permanent mandibular canine teeth belonging to the Anatomy Laboratory of the Department of Morphology, Piracicaba Dental School - University of Campinas UNICAMP.

For inclusion criteria, it was selected only permanent mandibular canine teeth showing complete rhyzogenesis. It was excluded from the sample deciduous teeth, teeth with deep caries, fractures, incomplete rhyzogenesis and those that presented with obturated root canal.

\section{Micro-CT scan}

The samples were scanned in a microtomography (SkyScan 1174, Belgium) by using

$50 \mathrm{kV}, 800 \mathrm{~mA}$. The thickness of the slices was $6 \mu \mathrm{m}$. The scans were exported to the NRecon Reconstruction software (SkyScan, Leuven, Belgium) to reconstruct the images three-dimensionally in axial sections presenting the attenuation coefficients of $\mathrm{x}$-rays with values related to the teeth tissue.

\section{Morphology analysis}

After three-dimensional reconstruction, the images were transferred to Mimics v. 18 (Materialise, Belgium) for analysis of the internal anatomy of the roots of the mandibular canines.

In this study, the classification of the root canal system was adopted according to Vertucci, ${ }^{14}$ namely:

Type I - single canal;

Type II - two distinct canals that join close to the apex;

Type III - a canal that divides into two within the root, joining in a canal in apical;

Type IV - two separate and distinct canals to the apex; two;

Type V - a canal that divides before the apex into

Type VI - two canals that unite in the body of the root and divide before the apex into two distinct canals;

Type VII - a canal that divides, then joins, into the body of the root and, again, divides into two at the apex;

Type VIII - three separate and distinct canals to the apex.

The shape of the root canal in four possible configurations: circular, oval, flattened, or eight shapes. This analysis was performed at three-thirds level: cervical, middle and apical. The evaluation was carried out in the own three-dimensional reconstruction, in the software Mimics v. 18 (Materialise, Belgium), observing a cross-section in each third.

The external anatomy of the root was analysed and classified regarding according to the existence or not of the mesial radicular grooves.

\section{Statistical analysis}

The R CRAN (open source) (WU Wien, TU Dortmund, U Oxford, AT\&T Research) software was used for statistical analysis. Descriptive analysis was performed by percentage to verify the most frequent root canal type in the lower canines. The descriptive analysis was performed in the form of a decision tree. The level of significance was $<0.05$.

\section{Results}

Three-dimensional reconstruction of the internal anatomy revealed that the most frequent canal was type I (92\%), followed by type III (8\%) (Figure 1).

In type I canals (Figures 2 and 4) the circular shape was the most frequent in the cervical and apical thirds and oval in the middle third, according to Figure 4. For the type III canals (Figures 3 and 5), the circular shape presented the most frequency in cervical and apical thirds, but in the middle third the eight and oval forms were frequent.

The analysis of the external anatomy showed that $84.84 \%$ of the teeth had mesial radicular grooves.

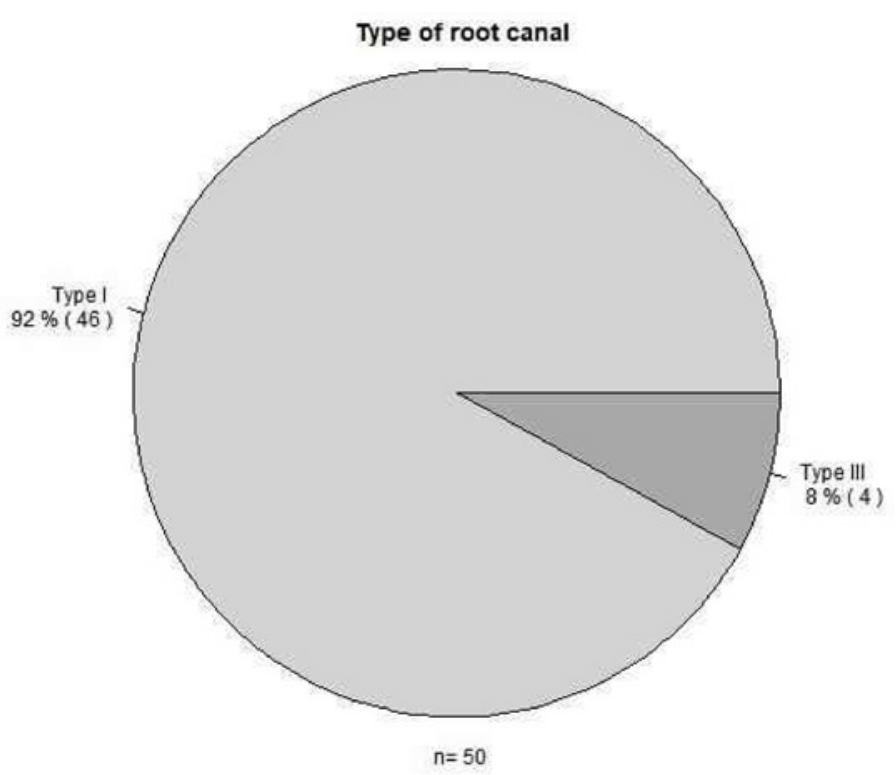

Figure 1. Graph representing the percentage of the internal anatomy evaluation according to the classification of Vertucci (12). It was observed that the most frequent root canal was type I - single canal. 


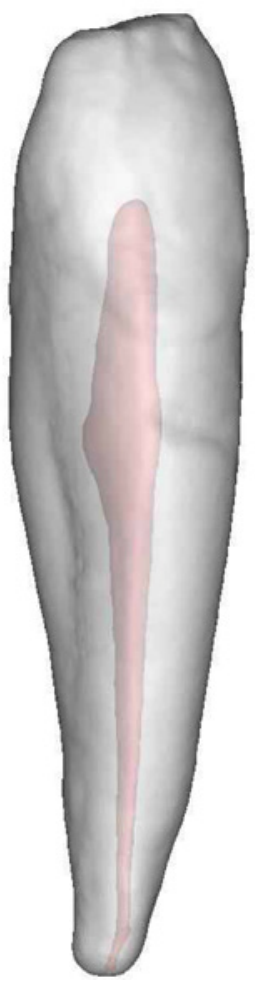

Figure 2. Three-dimensional model of the mandibular canine tooth obtained from Mimics v. 18 (Materialise, Belgium) for evaluation of the internal anatomy according to the classification of Vertucci (12). In red, by transparency, the obtained root canal, representing the type I - single root canal, is observed.

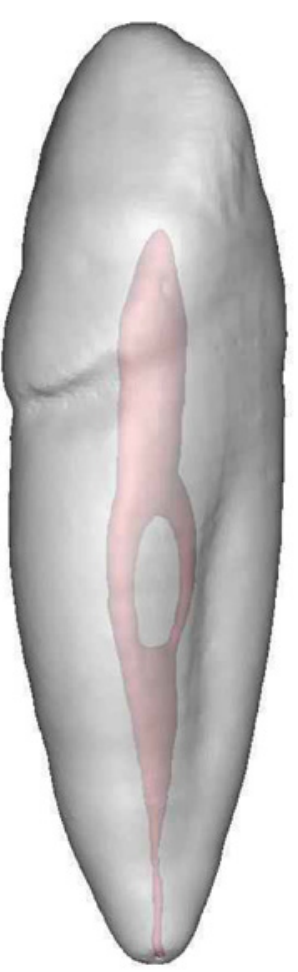

Figure 3. Three-dimensional model of the mandibular canine tooth obtained from Mimics v. 18 (Materialise, Belgium) for evaluation of the internal anatomy according to the classification of Vertucci (12). In red, through transparency, the root canal obtained, representing the type III - a canal that divides into two within the root, joining into an apical canal, is observed.

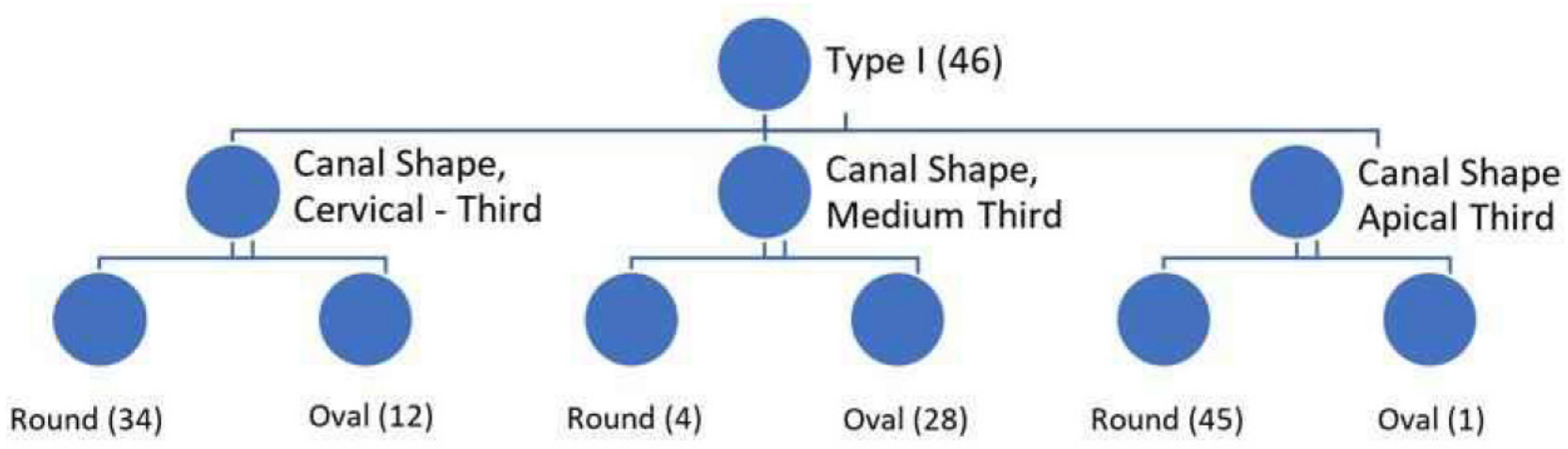

Figure 4. Decision tree showing the frequency of root canal shape in relation to the cervical, middle and apical thirds for Vertuccl (12) type I canal.

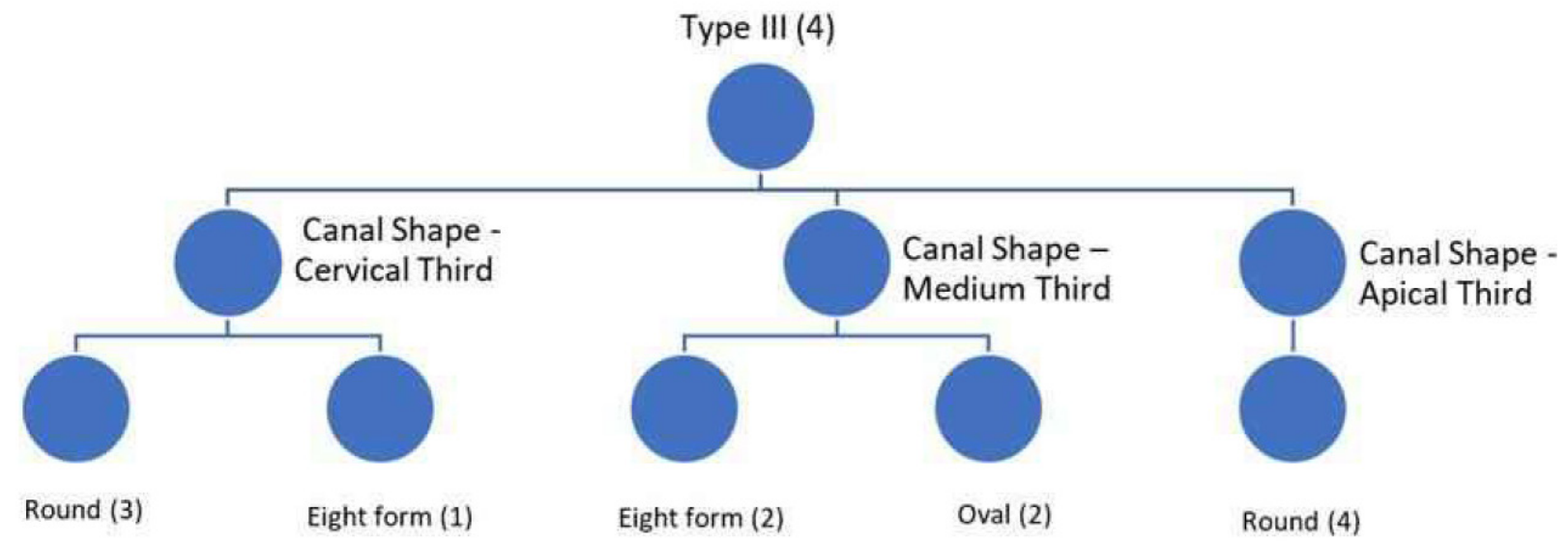

Figure 5. Decision tree showing the frequency of the root canal shape in relation to the cervical, middle and apical thirds for the Vertucci (12) type III canal. 


\section{Discussion}

The development of various areas of dentistry requires careful study of the morphology of human teeth, aiming to provide better oral health, restoring the function of the stomatognathic apparatus. ${ }^{6}$ In endodontics, a thorough knowledge of the internal anatomy of the teeth and the understanding of their possible variations are essential for the success of endodontic therapy. ${ }^{1}$

In the present study, micro-CT and threedimensional reconstruction were chosen because it was possible to verify the anatomy of the root canals with many details and the contrast obtained through the three-dimensional reconstruction inside the canal system with the surrounding dental tissues provided a three-dimensional view of the anatomy inferior canine root. Several supplementary configurations have been identified in different population groups using methods such as diaphanization ${ }^{10}$ and micro-CT. ${ }^{8,9}$

Sert et al. ${ }^{12}$ evaluated the internal anatomy of a sample of 1400 lower teeth of a Turkish population, containing incisors to molars. It was verified a variety of canal configurations in all groups of teeth, except for the lower canines, which presented the most frequent type I canals (152) followed by type II (32). The present study evaluated the internal anatomy of the lower canines. The most frequent canal type in the population studied in lower canines was type $\mathrm{I}^{12}$ From the early works to the most recent studies, it has been established that roots with a perfect, tapered canal and a single apical foramen constitutes an exception rather than a rule..$^{15}$ As in Vertucci study, ${ }^{14}$ the present research did not find types II and VII canals, whereas Velmurugan \& Sandhya ${ }^{15}$ verified the incidence of $6 \%$ of type II canal. The lower canines usually have a single conical or slightly flattened root in the mesio-distal direction, presenting a single, wide and rectilinear canal, type I canal, according to the classification used in this study.

Contrasting with the upper canines, lower canines have been reported in several studies ${ }^{16,17,18,19}$ with anatomical variations such as the presence of 3 canals, which was not found in the present study.

These variations of the types of canals can be attributed to genetic and racial factors. ${ }^{15}$ An example of racial influence on the root canal system could be observed in the study by Trope et $a .^{20}$ who found significant ethnic differences studying lower premolars comparing black and white patients in relation to number of roots and canals. The incidence of two or more canals in black patients was $32.8 \%$ while in whites it was $13.7 \%$. The proportion of two roots in black patients was $16.2 \%$ and $5.5 \%$ in whites.
Besides, the different results can be attributed to other variation factors such as: the age of the teeth evaluated, since in older patients there is a possibility of canals physiological calcifications, or even the causes of the indicated extractions. ${ }^{7}$

In the present study, $84.84 \%$ of the lower canines presented the mesial longitudinal sulcus. According to Ash, ${ }^{21}$ deep longitudinal development grooves found on the mesial surface of the dental root can influence the anatomical variations of the root canal system. Robinson et al. ${ }^{22}$ stated that radiographically the presence of this groove, depending on its depth, may suggest the false idea of an accessory root canal, making it difficult to perform endodontic treatment.

\section{Resumo}

O conhecimento da morfologia dos canais radiculares é importante para se alcançar sucesso em tratamentos endodônticos. Tem sido relatada a presença de raízes acessórias em dentes anteriores inferiores, sendo necessário melhorar novos métodos diagnósticos como a micro-CT. O objetivo do presente trabalho foi investigar a anatomia interna e externa de caninos inferiores permanentes utilizando micro-CT. Foram usados 50 caninos permanentes inferiores com rizogênese completa. Dentes decíduos, dentes com cáries profundas, fraturas, rizogênese incompleta e aqueles que apresentavam canais obturados foram excluídos. As amostras foram escaneadas no microtomógrafo (SkyScan 1174, Bélgica), com os parâmetros de 50 $\mathrm{kV}, 800 \mathrm{~mA}$. A espessura dos cortes foi de $6 \mu \mathrm{m}$. Após a reconstrução tridimensional, as imagens foram exportadas para o Mimics v. 18 (Materialise, Bélgica) para análise da anatomia interna das raízes dos canais mandibulares. Os caninos foram classificados do Tipo I ao VIII. A anatomia externa das raízes foi analisada e classificada de acordo com a existência ou não de sulcos mesiais radiculares (fendas mesiais incompletas nas raízes). O programa R CRAN (WU Wien, TU Dortmund, U Oxford, AT\&T Research) foi empregado para análise estatística. Uma análise descritiva foi feita por porcentagem para verificar o tipo mais frequente das raízes dos caninos, sendo empregada para tanto uma Árvore de Decisão. O nível de significância adotado foi $<0.05$. A reconstrução tridimensional da anatomia interna revelou que o tipo de canal mais frequente foi o tipo I (92\%), seguido do tipo III (8\%).

\section{Acknowledgments}

The authors would like to thank the National Council for Scientific and Technological Development (PIBIC/CNPq) for financial support. 


\section{References}

1. Vier-Pelisser FV, Dummer PM, Bryant S, Marca C, So MV, Figueiredo JA. The anatomy of the root canal system of three-rooted maxillary premolars analyzed using high-resolution computed tomography. Int Endod J 2010 Dec;43(12):1122-31. doi:10.1111/j.1365-2591.2010.01787. 2. Setzer FC, Kohli MR, Shah SB, Karabucak B, Kim S. Outcome of endodontic surgery: a meta-analysis of the literature--Part 2: Comparison of endodontic microsurgical techniques with and without the use of higher magnification. J Endod 2012 Jan;38(1):1-10. doi: 10.1016/j.joen.2011.09.021.

3. Miyashita M, Kasahara E. Root Canal System of the mandibular Incisor. J Endod. 1997; 23: 479-484.

4. Tiku AM, Kalaskar RR, Damle SG. An Unusual presentation of all the Mandibular Anterior Teeth with Two Root canals - A case report. J Indian Soc Pedod Prev Dent 2005 Oct-Dec;23(4):204-6.

5. Willershausen B, Kasaj A, Röhrig B, Marroquin BB. Radiographic investigation of frequency and location of root canal curvatures in human mandibular anterior incisor in vitro. J Endod 2008 Feb;34(2):152-6.

6. Martos J, Lubian C, Silveira LFM, Castro LAS, Luque CMF. Morphology analysis of the root apex in human teeth. J Endod 2010;36: 664-667. 7. Baratto Filho F, Zaitter S, Haragushiku GA, Campos EA, Abuabara A, Correr GM. Analysis of the internal anatomy of maxillary first molars by using different methods. J Endod 2009; 35(3): 337-342.

8. Milanezi de Almeida M, Bernardineli N, Ordinola-Zapata R, et al. Micro-computed tomography analysis of the root canal anatomy and prevalence of oval canals in mandibular incisors. J Endod 2013; 39: 1529-33.

9. Leoni GB, Versiani MA, Pecora JD, Damiao de Sousa-Neto M. Microcomputed tomographic analysis of the root canal morphology of mandibular incisors. J Endod 2014; 40:710-6.

10. Kaffe I, Kaufman A, Littner MM, Lazarson A. Radiographic study of the root canal system of mandibular anterior teeth. Int Endod J 1985 Oct; 18 (4):253-9.

11. Vertucci FJ. Root canal anatomy of the mandibular anterior teeth. J Am Dent Assoc 1974 Aug; 89(1-3):369-71.

12. Sert S, Bayirli GS. Evaluation of the root canal configurations of the mandibular and maxillary permanent teeth by gender in the Turkish population. J Endod 2004; 30: 391-8.

13. Sert S, Aslanalp V, Tanalp J. Investigation of the root canal configurations of mandibular permanent teeth in the Turkish population. Int Endod J 2004; 37: 494-9.

14. Vertucci, F. J. Root canal anatomy of the human permanent teeth. Oral Surg Oral Med Oral Pathol 1984 Nov; 58(5):589-99.

15. Velmurugan N, Sandhya R. Root canal morphology of mandibular first premolars in an Indian population: a laboratory study. Int Endod J 2009 Jan;42(1):54-8. doi: 10.1111/j.1365-2591.2008.01494.

16. Hession RW. Endodontic morphology. II. A radiographic analysis. Oral Surg Oral Med Oral Pathol Oral Radiol. 1977; 44: 610-20.

17. Mikrogeorgis G, Lyroudia KL, Nikopoulos N, Pitas I, Molyvdas I, Lambrianidis TH. 3D computer-aided reconstruction of six teeth with morphological abnormalities. Int Endod J 1999; 32: 88-93 18. Versiani MA, Pecora JD, Sousa-Neto MD. The anatomy of tworooted mandibular canines determined using micro-computed tomography. Int Endod J 2011; 44: 682-7.

19. Han T, Ma Y, Yang L, Chen X, Zhang X, Wang Y. A study of the root canal morphology of mandibular anterior teeth using cone-beam computed tomography in a Chinese subpopulation. J Endod 2014; 40: 1309-14.

20. Trope M, Elfenbein L, Tronstad L. Mandibular premolars with more than one root canal in different race groups. J Endod. 1986 Aug;12(8):343-5.

21. Ash M. Wheeler's Dental Anatomy: Physiology and Occlusion. 7th edition. Philadelphia: W.B. Saunders Company, p. 228-9, 1999.

22. Robinson S, Czerny C, Gahleitner A, Bernhart T, Kainberger FM. Dental CT evaluation of mandibular first premolar root configurations and canal variations. Oral Surg Oral Med Oral Pathol Oral Radiol Endod. 2002 Mar;93(3):328-32.

23. Pineda F. Roentgenographic investigation of the mesiobuccal root of the maxillary first molar. Oral Surg Oral Med Oral Pathol 1976; 36(2): 253-260.

24. Jiao K, Daí J, Wanga MQ, Niu LN, Yu SB, Liu XD. Age- and sexrelated changes of mandibular condylar cartilage and subchondral bone: A histomorphometric and micro-CT study in rats. Arch Oral Biol 2010; 55: 155-163.

25. Awawdeh LA, Al-Qudah AA. Root form and canal morphology of mandibular premolars in a Jordanian population. Int Endod J 2008; 41: 240-248.
Received: July 6, 2019

Accepted: abril 4, 2021
Corresponding author

Ana Cláudia Rossi

E-mail: anarossi@unicamp.br 